\title{
Bibliography of Personal Names, 1967
}

\section{ELSDON C. SMITH}

$\mathrm{I}_{\mathrm{r}}$

$L_{T}$ WILl BE APPRECIATED if members will call my attention to items I have missed, and also to items published in 1968 for the next annual installment of this bibliography.

Ashley, Leonard R. N. Pomp and its Circumstances in Names, Vol. 15, June, 1967, pp. 85-110. Potsdam (N.Y.), 1967.

On names of rulers.

Astour, Michael C., Some New Divine Names from Ugarit in American Oriental Society Journal, Vol. 86, July-September, 1966, pp. 277-284. Baltimore, 1966.

Backus, Joseph M., Two "No-Name" Poems in Names, Vol. 15, March, 1967, pp. 1-7. Potsdam (N.Y.), 1967.

Bardsley, Charles Wareing Endell, A Dictionary of English and Welsh Surnames Baltimore, 1967. Pp. xvi, 837.

A reprint of the book originally published, London, 1901.

Bessason, Haraldur, [Icelandic Names] in Scandinavian Studies, Vol. 39, May, 1967, pp. 132-137. Lawrence (Kans.), 1967.

Boganov, Victor, Ivan and Marya - Russian Names in Soviet Life, June, 1966, pp. 58-59. Washington (D.C.), 1966.

Borkowski, Casimir, An Experimental System for Automatic Identification of Personal Names and Personal Titles in Newspaper Texts in American Documentation, Vol. 18, July, 1967. Washington, 1967.

Bright, William, Karok makkay < Scottish McKay in Names, Vol. 15, September, 1967, pp. 235-236. Potsdam (N.Y.), 1967.

On this personal name becoming a $t$ rm for "white trapper."

Brown, Calvin S., Odysseus and Polyphemus: The Name and the Curse in Comparative Literature, Vol. 18, Summer, 1966, pp. 193-202. Eugene (Oreg.), 1966.

The success of the curse is identified with the power from knowledge of the name of Odysseus.

Brown, Samuel L., Surnames are the Fossils of Speech

[Minneapolis, Minn.], 1967. Pp. [x], 350.

Dictionary of miscellaneous surnames with meanings and derivations. 
Buechley, Robert W., Characteristic Name Sets of Spanish Populations

in Names, Vol. 15, March, 1967, pp. 53-69. Potsdam (N.Y.), 1967.

On Spanish-named populations.

Butters, D. H., Phonetic Name Searching - A New Technique in Insurance, Vol. 68, July 8, 1967, pp. $19+$.

New York, 1967.

Cavendish, Richard, The Cabala and the Names of Power

in his The Black Arts, Chapter 3, pp. 81-141 and passim. New York, 1967.

On the superstitious use of names.

Chandler, Alice, The Name Symbolism of Captain Vere

in Nineteenth Century Fiction, Vol. 22, June, 1967, pp. 86-89. Berkeley and Los Angeles (Calif.), 1967.

On names in literature.

Chaput, Donald, The Semantics of Nadowa

in Names, Vol. 15, September, 1967, pp. 228-234. Potsdam (N.Y.), 1967.

On the meaning of this Indian name.

Cottle, Basil, The Penguin Dictionary of Surnames

Harmondsworth (England), 1967. Pp. 335.

A dictionary of English surnames.

Evans, David Ellis, Gaulish Personal Names: a Study of Some Continental Celtic Formations

Oxford (England), 1967. Pp. xxiii, 492.

Filips, Katherine, The Names of Poets in Georgij Ivanov's Poetry in Names, Vol. 15, March, 1967, pp. 70-77. Potsdam (N.Y.), 1967.

On names in literature.

Fool-the-Squares

in Time, Vol. 90, December 15, 1967, p. 58. Chicago, 1967.

General on pseudonyms.

4000 Names for Your Baby

New York, 1967. Pp. 128.

List of girls' and boys' names with derivations, meanings, and variant and diminutive forms.

Goodenough, W. H., Personal Names and Modes of Address in Two Oceanic Societies

in Context and Meaning in Cultural Anthropology: in Honor of A. Irving Hallowell, edited by Melford Elliot Spiro, pp. 265-276. New York, 1965.

Greene, Linda and Harder, Kelsie B., Collections of the American Name Society, 1966

in Names, Vol. 15, March, 1967, pp. 78-82. Potsdam (N.Y.), 1967.

Bibliography on names.

Hassall, William Owen, History Through Surnames

Oxford (England), 1967. Pp. xv, 224.

A work for young students. 
Hector, L. C., Names, Medieval

in New Catholic Encyclopedia, Vol. 10, pp. 203-204. New York, 1967.

General on names.

Hughes, Pennethorne, Your Book of Surnames

London, 1967. Pp. 61.

A juvenile book.

I'm in the Copenhagen Phone Book

in Management Review, Vol. 56, July, 1967, pp. 46-49. New York, 1967.

Reprinted from New York Times of April 23, 1967, a translation from the February-March, 1967, issue of The Scandinavian Times, Copenhagen. On titles instead of first names in the Copenhagen phone book.

Jackson, Bruce, Prison Nicknames

in Western Folklore, Vol. 26, January, 1967, pp. 48-54. Berkeley (Calif.), 1967.

Kajanto, Tiro, Supernomina, A Study in Latin Epigraphy

[Commentationes Humanarum Litterarum Societas Scientiarum Fennica, Vol.

40 Nr. 1, 1966] Helsinki (Finland), 1966. Pp. 115.

On Roman agnomina and signa.

Kenny, Hamill, Introduction

in Names, Vol. 15, September, 1967, pp. 157-165. Potsdam (N.Y.), 1967.

An introduction to the special issue on Indian names, discussing past Indian name studies.

Ketcham, Rodney K., Investigation of Surnames as a Cultural Hobby in French Review, Vol. 40, January, 1967, pp. 368-376. Baltimore (Md.), 1967.

On French spot names.

Kolatch, Alfred J., The Name Dictionary, Modern English and Hebrew Names New York, 1967. Pp. xiii, 418.

On Jewish forenames and English equivalents. This is an enlarged revision of the author's These are the Names, first published New York, 1948.

Koš, Erih, Names

New York, 1966. Pp. vi, 152.

This is just a novel translated from the Serbo-Croat by Lovett F. Edwards.

Kulukundis, Elias, What's in a Name?

in his The Feasts of Memory, pp. 53-77. New York, 1967.

On naming customs in the Aegean island of Kasos.

Landau, Robert M., Name or Number - Which Shall it Be ?

in Names, Vol. 15, March, 1967, pp. 12-20. Potsdam (N.Y.), 1967.

Lindquist, Emory, Swedish American Pseudonyms: One Aspect of the Swedish Immigrant Literary Tradition

in The Swedish Pioneer Historical Quarterly, Vol. 18, July, 1967, pp. 148-156. Chicago, 1967.

Lyra, Franciszek, Polish Surnames in the United States

in American Speech, Vol. 41, February, 1966, pp. 39-44. New York, 1966. Mostly on change of names by Poles. 
McDavid, John W., and Harari, Herbert, Stereotyping of Names and Popularity in Grade-School Children

in Child Development, Vol. 37, June, 1966, pp. 453-459. Chicago, 1966.

Socially desirable names were found to be correlated with popularity.

Maduell, Charles R., The Romance of Spanish Surnames

New Orleans, 1967. Pp. xiii, 221.

Chiefly a list with linguistic origin, meanings, and comparative frequency, each surname being located as to geographic origin and distribution in the Iberian peninsula.

Matthews, Constance Mary, English Surnames London, 1966. Pp. 359.

A good comprehensive work.

Matthews, Constance Mary, English Surnames

New York, 1967. Pp. 367.

A reprint of the English edition above, with an added chapter on American surnames.

Matthews, Constance Mary, History in the Telephone Book in Horizon, Vol. 9, Winter, 1967, pp. 105-111. New York, 1967.

About surnames in the Manhattan telephone directory, and their relation to Jewish and British history.

Maxwell, J. C., The Name of Brutus

in Notes and Queries, Vol. 212, New Series Vol. 14, April, 1967, p. 136. London, 1967.

On Shakespeare's use of the name.

Mook, Maurice A., Nicknames Among the Amish

in Names, Vol. 15, June, 1967, pp. 111-118. Potsdam (N.Y.), 1967.

Reprint from The Morning Call, Allentown, Pa.

Murphy, F. X., Names, Christian

in New Catholic Encyclopedia, Vol. 10, pp. 201-203. New York, 1967.

Mostly on the names of early Christians.

Murphy, R. T. A., Name of God

in New Catholic Encyclopedia, Vol. 10, pp. 200-201. New York, 1967.

On reverence for the name of God.

Murphy, R. T. A., Yahweh

in New Catholic Encyclopedia, Vol. 14, pp. 1065-1066. New York, 1967.

On this name in the Bible.

O'Hara, John, If the Name Fits

in Holiday, Vol. 41, May, 1967, pp. 28, 30-31. Philadelphia, 1967.

On names used for characters in fiction.

Person, H. A., Swedes and Their Family Names in Scandinavian Studies, Vol. 39, August, 1967, pp. 209-248. Lawrence (Kans.), 1967.

Rayburn, J. A., The Term Amerindian

in Names, Vol. 15, September, 1967, pp. 237-238. Potsdam (N.Y.), 1967. 
Reaney, P. H., The Origin of English Surnames

London, 1967. Pp. xix, 415.

General on English surnames.

Rennick, Robert M., The Folklore of Curious and Unusual Names

in New York Folklore Quarterly, Vol. 22, March, 1966, pp. 5-14.

Cooperstown (N.Y.), 1966.

A discussion of odd names.

Roche, O. I. A., American Huguenot Names

in his The Days of the Upright, pp. 322-328. New York, 1965.

Mostly just a list.

Rosenthal, Eric, South African Surnames

Cape Town (South Africa), 1965. Pp. 262.

In two parts, biography of 161 pages and dictionary of names with meanings and nationalities of 90 pages.

Sabourin, Leopold, The Names and Titles of Jesus

New York, 1967. Pp. xviii, 334.

A discussion of about fifty names of Jesus.

Searle, John R., Proper Names and Descriptions

in The Encyclopedia of Philosophy, Vol. 6, pp. 487-491. New York, 1967.

On the theory of names.

Smith, Elsdon C., Bibliography of Personal Names, 1966

in Names, Vol. 15, June, 1967, pp. 142-149. Potsdam (N.Y.), 1967.

Smith, Elsdon C., Naming the Baby

in Catholic Digest, Vol. 32, November, 1967, pp. 119-120. Huntington (Ind.), 1967.

Smith, Elsdon C., Treasury of Name Lore

New York, 1967. Pp. ix, 246.

Miscellaneous articles on personal names.

Streshinsky, Shirley G., How to Choose the Right Name for Your Baby in Parents Magazine, Vol. 42, October, 1967, pp. 62, 96-97. New York, 1967.

Ware, N. J., Testimony of Classical Names in Support of Metrical Regularity in the Libro de Alexandre

in Hispanic Review, Vol. 35, July, 1967, pp. 211-226. Philadelphia, 1967.

On names in literature.

Withycombe, Elizabeth Gidley, Name

in Chambers's Encyclopedia, New Revised Edition, Vol. 9, pp. 646-649.

Oxford (England), 1967.

General on personal names.

Woulfe, Patrick, Irish Names and Surnames

Baltimore, 1967. Pp. xlviii, 696.

Reprint by Genealogical Publishing Company;

originally published in Dublin, 1923. 